ROCZNIKI TEOLOGICZNE

Tom LXVI, zeszyt 9 - 2019

DOI: http://dx.do.org/10.18290/rt.2019.66.9-8

DOROTA ŚWITAŁA-TRYBEK

\title{
MATERIALNE I NIEMATERIANE PRZEJAWY KULTU ŚW. BARBARY W ŚRODOWISKU GÓRNICZYM
}

\author{
MATERIAL AND IMMATERIAL MANIFESTATIONS OF CULT \\ OF ST. BARBARA IN THE MINING COMMUNITY
}

\begin{abstract}
A b s t r a c t. The cult of St. Barbara in the professional environment of miners takes many different forms. It has been developing in Upper Silesia since the first half of the 19th century and is related to the intensive development of the mining industry in this area. The most characteristic material and immaterial manifestations of the cult of St. Barbara include: churches and chapels under her invocation, paintings and statues depicting the patron of miners, functioning brotherhoods of St. Barbara, songs and prayers to St. Barbara, celebrating the 4th December as a patron and professional holiday (so-called Barbórka), which was inscribed on the National List of Intangible Cultural Heritage in 2018.
\end{abstract}

Key words: Silesia; St. Barbara; cult; mining; religiosity.

Od schyłku starożytności cześć oddawana świętym stała się nieodłącznym elementem historii chrześcijaństwa (Brown, 2007, s. 1). W kulturze religijnej święci i błogosławieni pełnią ważne role, a ich kult - od samego początku - miał charakter utylitarny i jest związany z wiarą w bezpośrednią interwencję w życie codzienne (Tomicki, 1976, s. 45). Każdemu z nich przypada określona „dziedzina, w której zwykle rozwija działalność dobroczynną, zmieniając naturalne zjawiska dzięki nadprzyrodzonemu wpływowi, jaki roztacza" (Thomas, Znaniecki, 1976, s. 205). Wiedza o ,profesji” poszczególnych świę-

Dr hab. Dorota ŚwITAŁA-TRYBEK, prof. UO - Katedra Kulturoznawstwa i Folklorystyki, Instytut Polonistyki i Kulturoznawstwa Uniwersytetu Opolskiego, pl. Kopernika 11, 45-040 Opole; e-mail: dtrybek@uni.opole.pl; ORCID: https://orcid.org/0000-0001-8525-5800 
tych była i jest nadal przekazywana z pokolenia na pokolenie. Warto chociażby wspomnieć, iż do określonych patronów w różnych potrzebach zwracaja się wierni (w modlitwach, pieśniach, podczas nabożeństw) z prośbami o wstawiennictwo w wyproszeniu u Boga konkretnych łask (Gloger, 1972, s. 329330). Popularność niektórych świętych i błogosławionych, mimo upływu czasu i nowych postaci wyniesionych na ołtarze, nie słabnie, co świadczy o tym, że ich kult ma silne umocowanie w religijności ludowej, jak np. święci: Antoni Padewski (patron rzeczy zgubionych), Juda Tadeusz, Rita (od spraw beznadziejnych), Józef, Barbara (patroni konania, dobrej śmierci), Agata (od ognia i klęsk żywiołowych), Krzysztof (patron kierowców, podróżnych), Izydor, Urban (patron rolników) itd.

Przedmiotem artykułu są wybrane materialne i niematerialne przejawy kultu św. Barbary wśród górników kopalń węgla kamiennego na obszarze obecnego województwa śląskiego. Materiały, które stały się podstawą omówienia, pochodzą z badań terenowych (obserwacja uczestnicząca, wywiady), które autorka prowadziła w latach 2006-2018 w środowiskach górniczych, jak i z dostępnej na ten temat literatury przedmiotu.

\section{WOKÓŁ POSTACI I KULTU ŚW. BARBARY}

Od wczesnego średniowiecza do grona powszechnie czczonych świętych w Europie należy św. Barbara. Do jej kultu rozwijającego się od VI wieku, początkowo na Wschodzie (w Kościele prawosławnym Wielikomuczenica Warwara), później na Zachodzie, przyczynił się Symeon Metafrastes, jeden z najbardziej znanych hagiografów bizantyjskich, autor Zbioru żywotów świętych (Menologion) (Jurewicz, 1984, s. 194-195). Nieco później, bo od XIII wieku, duże znaczenie w kształtowaniu się czci świętych (w tym i Barbary) miała Złota legenda (Legenda aurea) błogosławionego Jakuba de Voragine. $\mathrm{W}$ polskich tłumaczeniach i wydaniach jednakże nie zamieszczono fragmentów o św. Barbarze.

$\mathrm{Na}$ ziemiach polskich najstarsze ślady kultu św. Barbary pochodzą z XI (nota w kalendarzu Modlitewnika Gertrudy, córki Mieszka II) i z początku XII wieku (formuły błogosławieństwa na 4 grudnia w Benedykcjonale krakowskim). Od XV wieku jest ona patronką Wydziału Teologicznego Akademii Krakowskiej, także powstałej w 1919 roku Akademii Górniczo-Hutniczej w Krakowie. Siedmiometrową figurę z jej podobizną można zobaczyć nad wejściem do gmachu głównego uczelni. Informacje dotyczące świętej pojawiają się w Żywotach świętych ks. Piotra Skargi, w tym m.in. opis cudu, jaki 
miał miejsce w 1418 roku dzięki wstawiennictwu patronki dobrej śmierci (Skarga, 1936, s. 377-378). Wielkim orędownikiem św. Barbary był Stanisław Kostka. Gdy ciężko zachorował, zwrócił się do niej z prośbą o przyjęcie Komunii Świętej, którą przyniosła mu w towarzystwie dwóch aniołów (Zalewski, 1989, s. 551). Do rozwoju kultu św. Barbary na Pomorzu, Warmii i w Prusach, co ma wyraz w licznych kaplicach, ołtarzach i kościołach, przyczynili się w XII wieku norbertanie, a po 1226 roku Zakon Najświętszej Maryi Panny (tj. Krzyżacy). Dzięki obecności relikwii świętej (herma z czaszką) w Starogrodzie stała się ona patronką dzieła chrystianizacji Prus, jak i całego państwa zakonu krzyżackiego (Rozynkowski, 2005, s. 17-18). Z kolei na Śląsk i do Małopolski kult św. Barbary przenikał z Czech, Saksonii oraz Austrii i był związany z rozwojem górnictwa na tym terenie.

Co wiemy o św. Barbarze? Do dzisiaj trwaja spory, czy postać taka w ogóle istniała (Zalewski, 1989, s. 752). W Encyklopedii Katolickiej podano, że św. Barbara (4 grudnia), dziewica i męczennica, należy do grona czternastu wspomożycieli, jest patronką dobrej śmierci, górników, flisaków i artylerzystów. Według legend była córką Dioskura z Nikomedii (lub Heliopolis) w Bitynii, przez którego została ścięta mieczem w 306 roku za przyjęcie chrześcijaństwa. W Kościele powszechnym jej wspomnienie obowiązywało do 1969 roku (Górecka, 1976, s. 14), po czym przeniesiono je do kościołów lokalnych.

Św. Barbara w religijności ludowej uważana jest za orędowniczkę dobrej śmierci (Kupisiński, 1997, s. 39; Turek, 2005, s. 297-30), nazywana także w pieśniach religijnych patronką konania (Dygacz, 2004), nawróconych; chroni od nagłej i niespodziewanej śmierci, dlatego wybrali ją na opiekunkę przedstawiciele zawodów, którzy narażeni są na niebezpieczeństwo utraty życia: górnicy, marynarze, flisacy, rybacy, artylerzyści, hutnicy, strażacy, żołnierze, kamieniarze, więźniowie itp. (Zalewski, 1989, s. 752), współcześnie także budowniczowie metra ${ }^{1}$, np. w Niemczech. Wymienia się ją również jako opiekunkę cnotliwych narzeczonych i życia rodzinnego (Kupisiński, 2012, s. 245). Wizerunek świętej widnieje na sztandarach żałobnych, wiele kaplic cmentarnych jest pod jej wezwaniem. Św. Barbarę określano również „Panią Błyskawic” i wzywano w trakcie burzy, modlono się do niej podczas różnych epidemii, prosząc o oddalenie „morowego powietrza” (Zadrożyńska, Braun, 2003, s. 243), o czym świadczy następująca inskrypcja na kolumnie św. Barbary w Warszawie (u zbiegu ulic Ludnej i Solec): Święta Barbaro

\footnotetext{
${ }^{1}$ Zob. https://www.katholisch.de/glaube/unser-kirchenjahr/legendare-martyrerin (21. 02. 2019).
} 
która mieszkasz w niebie / Proś za nami Pana w każdej potrzebie / Oddal precz od nas powietrze morowe / I racz uprosić dla nas lata zdrowe / A za wyświadczone ku nam opieki / Chwalić ciebie będziem po wszystkie wieki (Świtała-Trybek, 2015, s. 52). Z kolei w Barbarce pod Toruniem (znanym od średniowiecza ośrodku kultu św. Barbary) płynącemu tam niegdyś źródełku przypisywano cudowne właściwości, jego woda miała być pomocna w pozbyciu się kołtunów (po ich zamoczeniu odpadały), także w leczeniu chorób oczu (Jeziorski, 2005, s. 90).

Biografia św. Barbary (pochodzenie, śmierć i następnie patronat) stała się tematem licznych legend i podań, w tym górniczych, krzyżackich oraz związanych z kapliczkami (Świtała-Trybek, 2016, s. 44-53) i znalazła wyraz w wyrazistych symbolach, które nieodłącznie towarzyszą jej wizerunkom. Święta ta w ikonografii przedstawiana jest zazwyczaj w stroju królewskim z koroną na głowie, z palmą (znak męczeństwa, ale i zwycięstwa), na tle wieży z trzema oknami, trzyma kielich bądź monstrancję, pawie lub strusie pióro, księgę (Janicka-Krzywda, 1988, s. 30). W środowiskach górniczych dodatkowym jej atrybutem są bryły węgla albo wgłębienie skalne, szyby górnicze, które bezpośrednio wskazują na opiekę nad osobami pracującymi w kopalni.

W europejskiej i polskiej tradycji ludowej w dniu św. Barbary występowały liczne zachowania zwyczajowe, np. umieszczano gałązki czereśni lub śliwy w naczyniu z wodą, które miały zakwitnąć na Boże Narodzenie, co było odbierane jako dobry znak na nadchodzący rok (Ogrodowska, 2008, s. 65). Zwyczaj ten jeszcze współcześnie praktykuje się w Niemczech (Westfalia, Bawaria) oraz w Austrii (Tyrol), gdzie jest on nazywany Barbarazweig (Wolf, 2005, s. 35; Nussbaumer-Keller, 2004). Natomiast we Francji (Prowansja) do małej miski z przygotowanym podłożem wysiewa się zboże, nazywane pszenica św. Barbary (le blé de Sainte Barbe) (Večerkova, Frolcová, 2010, s. 159). Dawniej na Śląsku w wigilię dnia 4 grudnia dziewczęta czyniły wróżby matrymonialne, np. potrząsały płotem i nasłuchiwały szczekania psa. Z tej strony, z której dobiegał jego głos, miał przyjść kawaler. Zabieg ten powtarzały także w wigilię Bożego Narodzenia (Pośpiech, 1987, s. 20). Z kolei w Bułgarii w dniu św. Barbary wykonywano różne czynności rytualne mające chronić przed chorobami, w tym przed ospą (Mihaylova, 2012, s. 140-142).

Znanych jest też wiele przysłów pogodowych związanych z 4 grudnia i św. Barbarą, np. „Święta Barbara po wodzie, Boże Narodzenie po lodzie”, „W św. Barbarkę włóż sanie na górkę”, „Kiedy na św. Barbarę błoto, będzie zima jak złoto”, „Na św. Barbarę jeżeli mróz i pogoda, zima będzie lekka i bez śniegu" (Adalberg, 1889-1894, s. 13). 


\section{KULT ŚW. BARBARY W ŚRODOWISKU GÓRNICZYM}

Grupa zawodowa górników ,wytworzyła najbogatszą odrębną kulturę jednej grupy zawodowej. Elementami tego dziedzictwa są jedyne w swoim rodzaju zjawiska kulturowe, takie jak: swoista więź kamractwa, obyczajowość, humor, specyficzna struktura rodziny górniczej, odrębne zwyczaje i wierzenia, także swoista twórczość artystyczna górników" (Simonides, 2010, s. 21-22). W obyczajowości górniczej ważne miejsce zajmuje kult św. Barbary, wyrażający się w wielu zróżnicowanych formach, które współtworzą obraz kultury religijnej górników.

Przyjmuje się, że kult św. Barbary - jako patronki górników - występował już w XIII wieku i był związany z kopalniami kruszcowymi na Dolnym Śląsku. W bitwie z Tatarami pod Legnicą (1241 r.) po stronie rycerstwa (polskiego i niemieckiego) walczyło 600 gwarków (wówczas wolnych rzemieślników) z okręgu Goldberg (Złotoryja) (Piecha, 2002, s. 56-57). W regionie tym znajdują się najstarsze kościoły pochodzące z końca XIII i początku XIV wieku, którym patronuje św. Barbara, w tym w Borzygniewie, Stoszowicach Dolnych, Pastuchowie oraz liczne kaplice powstałe we Wrocławiu i innych miejscowościach: Droszkowie, Namysłowie, Pomianowie (Neuling, 1902, s. 362-363). Z kolei na Górnym Śląsku kult św. Barbary - opiekunki górniczego stanu - kształtował się kilka wieków później wraz z intensywnym rozwojem górnictwa węglowego na tym obszarze, szczególnie na przełomie XIX i XX wieku. Jednakże już w 1747 roku w Tarnowskich Górach bulla papieża Benedykta XIV zostało zatwierdzone (funkcjonowało już wcześniej) pierwsze bractwo zrzeszające górników ze Śląska, z tej okazji wydano wówczas modlitewnik (Kossakowska-Jarosz, Górecki, 2018). W okresie późniejszym takowe bractwa zakładano w wielu miejscowościach: Królewskiej Hucie, Zabrzu, Bytomiu, Pszowie, Radlinie, Świętochłowicach, Lipinach. Górnicy górnośląscy, którzy wyjeżdżali do pracy w Zagłębiu Ruhry, również zakładali bractwa św. Barbary, np. w Gelsenkirchen (1883), Dellwig (1889), Oberhausen (1900), Hamborn (1900), Lünen (1900) (Myszor, 1993).

Św. Barbara, według legend, została wybrana przez górników na patronkę za sprawą skał (groty), w których schowała się przed swoim oprawcą - ojcem. Mimo że nie udało się jej ocalić życia (zdradził ją pastuch), to przywodzą one na myśl wyrobiska pod ziemią, gdzie na pracujących tam mężczyzn czyhaja różnego rodzaju niebezpieczeństwa, narażeni są oni na wypadki i katastrofy. Patronka dobrej śmierci, która w chwili konania została cudownie posilona Najświętszym Sakramentem, ma czuwać nad nimi w pracy, aby nic złego im się nie stało (Bazielich, 1988, s. 351; Gerlich, 1995, s. 28-31). Opieka św. Barbary nad 
grupą zawodową górników utrwalona została również w przysłowiach: „Barbara święta o górnikach pamięta” „Gdy górnik pracuje w nocy, to mu święta Barbórka stoi przy pomocy”; „Komu Barbórka przaje, ten się z dziada panem staje” (Ligęza 1968, s. 92 i 95; Czubala, 1988, s. 417-418).

Jednym z wyraźnych przejawów kultu świętych na danym obszarze jest nadawanie ich imion kościołom i kaplicom. Sa to zazwyczaj postaci bezpośrednio związane z danym regionem, miejscowością poprzez miejsce swojego urodzenia, śmierci, prowadzoną działalność (duszpasterską, misyjną), a także charakter terenu (np. rolniczy, przemysłowy). Górny Śląsk (wschodnia jego część) i Zagłębie Dąbrowskie kojarzą się przede wszystkim z obszarem uprzemysłowionym, w którym przez ostatnie dwa stulecia rytm życia mieszkańców wyznaczała praca $w$ kopalniach i hutach. Nie dziwi przeto fakt, że w wielu miejscowościach znajdują się kościoły pod wezwaniem św. Barbary. Są wśród nich świątynie wybudowane w XIX i pierwszej połowie XX wieku (Adamski, 1939, s. 20) w dawnych ośrodkach górniczych (jak np. w Chorzowie, Bytomiu, Sosnowcu, Będzinie), jak i świątynie powstałe kilka dekad temu, ale również zlokalizowane w parafiach, w których duża część mieszkańców zawodowo była (lub jest nadal) związana z zakładami wydobywczymi (np. w Rybniku-Boguszowicach, Rudzie Śląskiej-Bykowinie, Katowicach-Giszowcu, Bieruniu, Czechowicach-Dziedzicach, Zabrzu). Św. Barbara razem ze świętymi: Jackiem i Florianem (patronami hutników i strażaków) oraz Matką Boską Piekarską - jest również patronką archidiecezji katowickiej (Cichy, 1998, s. 7-18). Ona też została wybrana na patronkę dwóch miast - ośrodków górniczych: Rudy Śląskiej (1993 r.) i Knurowa (2018 r.). Św. Barbara widnieje także od 1998 roku w herbie pierwszego z nich. Jej imieniem nazwano największy szpital specjalistyczny w Zagłębiu Dąbrowskim, który został oddany do użytku w 1988 roku w Sosnowcu na potrzeby leczenia górników. Poszczególne poziomy szpitala budowała inna kopalnia.

Do najstarszych i jednocześnie najbardziej wyróżniających się praktyk religijnych górników od połowy XIX wieku należały wspólne modlitwy przed rozpoczęciem pracy (Ciszewski, 1886, s. 209-210; Piecha-van Schagen, 2018, s. 55-60). Odbywały się one w cechowniach (zob. fot. 1 i 2), gdzie znajdowały się ołtarze ku czci św. Barbary, prowadził je starszy wiekiem górnik, zwany śpiywokiem (Ligęza, Żywirska, 1964, s. 169). W niektórych kopalniach kaplice patronki dobrej śmierci mieściły się w podziemiach kopalni. O codziennej praktyce odprawiania zbiorowych nabożeństw górników przed szych$t a$ pisał już w latach 40. XIX wieku Hieronim Łabęcki: „Jest odwieczny zwyczaj, iż górnicy przed rozpoczęciem swej szychty, czyli godzin pracy, schodzą się do jaty kopalnej, to jest domku zgromadzenia przy kopalni i tam 
przed udaniem się do pracy wspólnie modlitwy odmawiają; gdy górnicy zmieniają się rano i wieczór skoro 12 godzinnemi szychtami robią, a zaś trzy razy dziennie gdy tylko 8 godzinnemi pracują [...] przeto odmawiają nabożeństwa ranne, południowe i wieczorne, $\mathrm{z}$ tych zwykle w południe najkrótsze. Litanije do S. Barbary, do SS. Aniołów Stróżów prócz właściwych do pory dnia modlitw, najczęściej są odmawiane" (Łabęcki, 1842, s, 151-152).

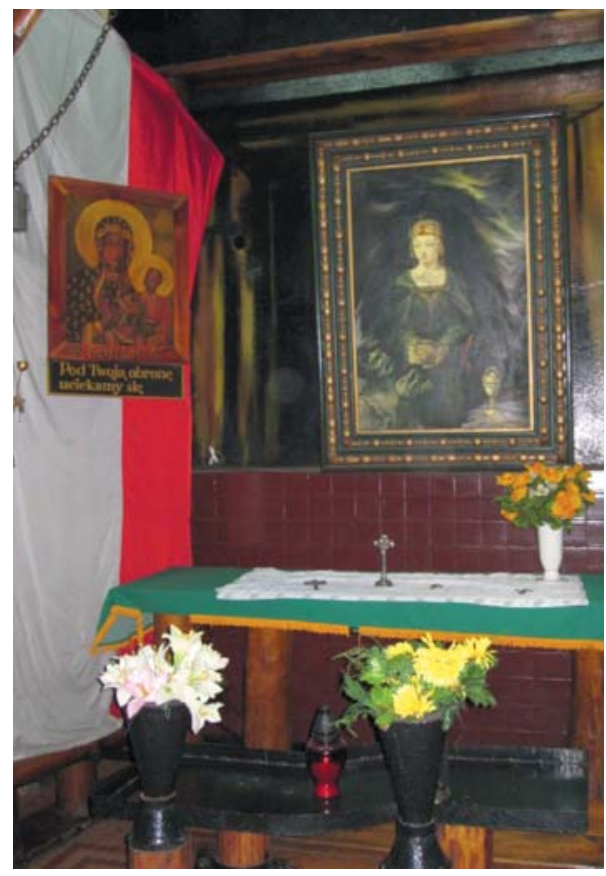

Fot. 1. Ołtarz św. Barbary w zlikwidowanej kopalni „Nowy Wirek” (2010 r., fot. D. Świtała-Trybek)

Nabożeństwom tym górnicy przypisywali znaczenie zabezpieczające, dlatego skrupulatnie w nich uczestniczyli, korzystając przy tym ze specjalnych modlitewników, w tym z Magazynu duchownego opracowanego przez nadsztygara Mateusza Lissa (Liss, 1840), także z Memento mori ks. Józefa Szafranka (Szafranek, 1859) czy zbiorów pieśni, np. Karola Janitzka - organisty z Biskupic (Janitzek, 1879). Od lat 60. XIX wieku władze górnicze zaczęły wprowadzać rozporządzenia, czyniąc z tej praktyki religijnej przymus obwarowany karami za każdą nieobecność na porannej modlitwie. Zwyczaj odprawiania zbiorowych modłów zaczął zanikać w latach międzywojennych, ustępując miejsca indywidualnym modlitwom górników przed obrazami św. Barbary 


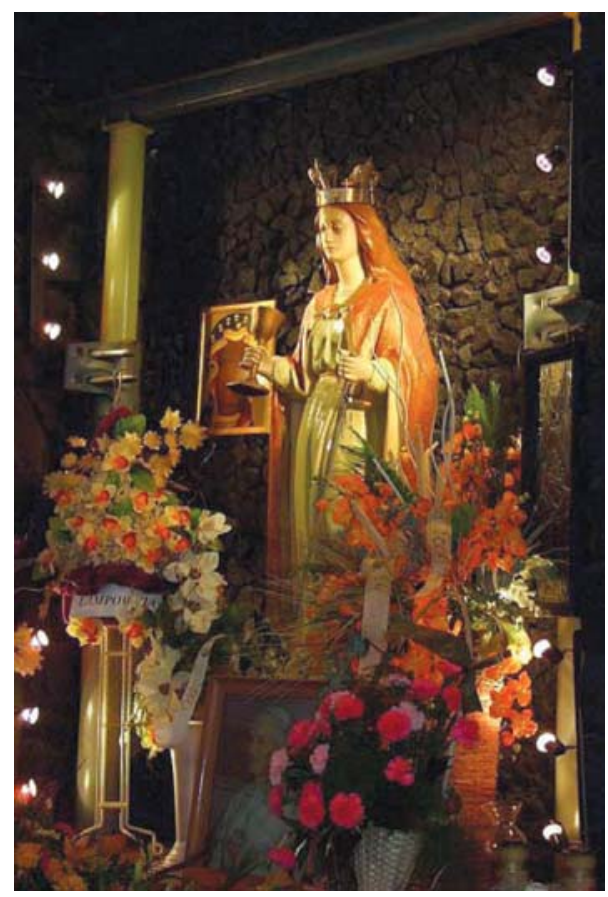

Fot. 2. Figura św. Barbary w cechowni kopalni „Halemba” (2012 r., fot. D. Świtała-Trybek)

(Ligęza, Żywirska, 1964, s. 169-170). Po drugiej wojnie światowej losy wizerunków św. Barbary w cechowniach stały się niewygodne dla ówczesnej władzy komunistycznej, były bowiem w sprzeczności z propagowaną ideologią świeckości państwa, stąd od 1948 roku nakazano ich usuwanie. Po 1956 roku znów „na krótko” pojawiły się w kopalniach, by w latach 70. ostatecznie zniknąć (Myszor, 1993). Przed zniszczeniem wielu tych obiektów kultu uchroniła je postawa górników, którzy w tajemnicy, pod groźbą represji ze strony służb bezpieczeństwa, ukrywali je lub też oddawali „na przechowanie” do kościołów czy muzeów (Bukowska-Floreńska, 2007, s. 177). Powrót wizerunków św. Barbary do kopalń w latach 80 . był wyrazem determinacji środowiska górniczego i miał on ,bezpośredni związek ze strajkami górników na przełomie sierpnia i września 1980 roku. Żądania przywrócenia usuniętych obiektów kultu stanowiły w wielu zakładach część postulatów strajkowych" [Piecha-van Schagen, 2018, s. 614). Jeśli niemożliwa była impostacja przedstawień patronki we wspomnianych cechowniach, wówczas wznoszono ku jej czci kapliczki na terenie kopalń czy miejscowości (np. w Zabrzu, Rudzie 
Śląskiej). Odnowienie kultu św. Barbary w śląskich kopalniach przyjmowało bardzo uroczystą oprawę.

Oprócz licznych świątyń pod wezwaniem św. Barbary bardzo wyraźnym wyrazem jej kultu są także przedstawienia w parafialnych kościołach, np. w prezbiterium, w kaplicach i nawach bocznych. Podkreślić trzeba, że zdecydowana większość tychże obrazów i figur została w nich zamieszczona $\mathrm{z}$ inicjatywy samych parafian - pracowników kopalń, którzy pragną św. Barbarę „mieć w swoim kościele”. Szczególną wymowę mają wizerunki przeniesione do lokalnych kościołów z cechowni likwidowanych kopaln. Z praktyką tą spotykamy się od lat 90 . ubiegłego stulecia, kiedy rozpoczęła się restrukturyzacja przemysłu wydobywczego w Polsce. Wprowadzenie obrazów i figur ma bardzo podniosły charakter, górnicy ubrani są w strojach galowych, uroczystościom przewodzą biskupi, którzy dokonują konsekracji przedstawień. Jest to przejmujący moment dla górników i pozostałych mieszkańców, jak sami podkreślają „bolesną ceremonią”, ,symbolicznym końcem życia byłego zakładu"3, z którym były związane kolejne pokolenia.

Obrazy i figury św. Barbary w kościołach i kaplicach nabierają jeszcze większej wymowy w chwili wystąpienia katastrofy w kopalni. Wówczas przed jej wizerunkami gromadzą się wierni i modlą w intencji ofiar i ich rodzin. Odprawiane są specjalne nabożeństwa do św. Barbary o powodzenie w akcji ratowniczej. Kiedy w 2010 roku zostali uwięzieni górnicy w chilijskiej kopalni złota i miedzi, w kaplicy św. Barbary w Katowicach (przy Silesia City Center) odbywało się modlitewne czuwanie i przez ponad 60 dni (tyle trwała akcja ratownicza) płonął „święty ogień nadziei” (Świtała-Trybek, 2014, s. 157-158) (zob. fot. 3).

Realia codzienności górniczej, niebezpieczna praca, świadomość utraty życia w podziemnych wyrobiskach i ufność górników oraz członków ich rodzin w opiekę św. Barbary wyraża się również poprzez prywatne odmawianie do niej modlitw-westchnień (Gerlich, 2003, s. 110-111). W trakcie prowadzonych wywiadów informatorzy przywołali następujące przykłady takich właśnie próśb: „Święta Barbaro, proszę Cię o szczęśliwy powrót męża do domu” [zapis. w Zabrzu-Pawłowie w 2012 r.], „Święta Barbaro, miej go w swojej opiece” [zapis. w Rudzie Śląskiej-Halembie w 2012 r.]; „Ś Śięta

\footnotetext{
${ }^{2}$ Cyt. za: http://www.parafiambczwodzislaw.katowice.opoka.org.pl/ index.php?option=com _content\&view=article\&id=10\&Itemid=1 (15.02.2019).

${ }^{3}$ Cyt.za:http://myslowice.naszemiasto.pl/artykul/kopalnia-myslowice-wyniesli-obraz-sw-ba rbary-z-cechowni-to,2626552, artgal,t,id,tm.html (15.02.2019).
} 


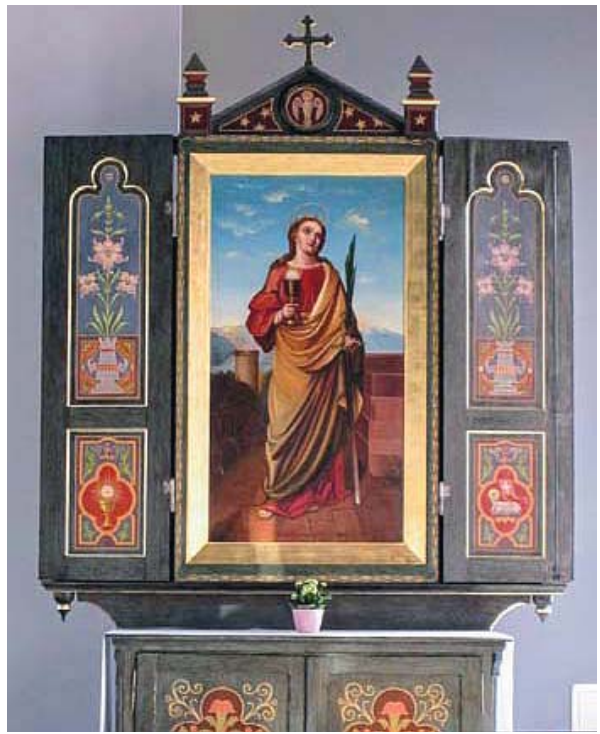

Fot. 3. Ołtarz św. Barbary w kaplicy pod jej wezwaniem (przy centrum handlowym Silesia City Center w Katowicach, 2018 r., fot. D. Świtała-Trybek)

Barbaro, aby nic mu się złego nie przytrafiło" [zapis. w Rudzie Śląskiej-Bielszowicach w 2012 r.], „Święta Barbaro, wejrzyj na mnie na dole” [zapis. w Mikołowie w 2013 r.]. W każdej też rodzinie górniczej znajdują się wizerunki patronki górniczego stanu, często wykonane z węgla (figurki, płaskorzeźby, zob. fot. 4-5), górnicy noszą przy sobie także poświęcone medaliki z jej obliczem. Stosunkowo nową formą są tatuaże przedstawiające św. Barbarę (również symbole górnicze, szyby kopalniane itp.), którymi górnicy ozdabiają swoje ciała, traktując je jak swego rodzaju amulety ochraniające ich przed wypadkami pod ziemią ${ }^{4}$.

W katalogu zachowań religijnych, praktykowanych w środowisku górniczym, niewątpliwie ważne miejsce zajmuje obchodzenie uroczystości patronalnej opiekunki górniczego stanu, będące jednocześnie świętem zawodowym osób pracujących w kopalniach (nie tylko węglowych). W dniu 4 grudnia, zwanym powszechnie Barbórką, zachował się wyraźny podział na religijne celebrowanie tej uroczystości najpierw w kościele i dopiero później następuje świeckie świętowanie w gronie znajomych i krewnych (co stanowi odrębne

\footnotetext{
${ }^{4}$ https://dziennikzachodni.pl/tatuaz-z-kopalnia-jak-tatuuja-sie-gornicy/ar/1057356(21.02.2019).
} 


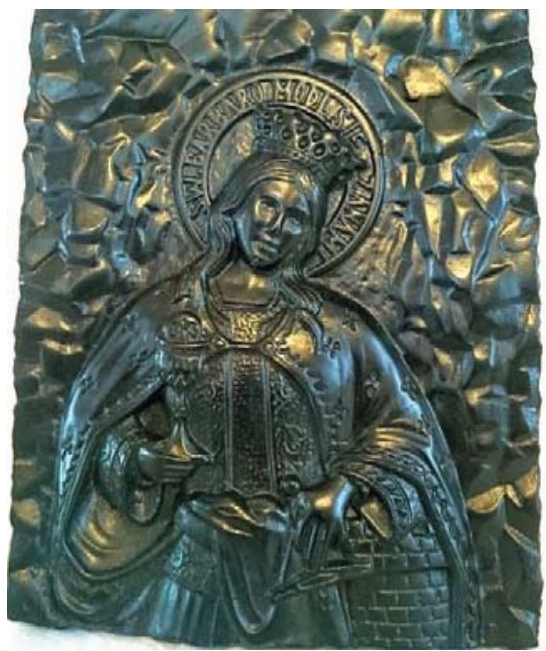

Fot. 4. Płaskorzeźba z węgla przedstawiająca św. Barbarę (fot. D. Świtała-Trybek)

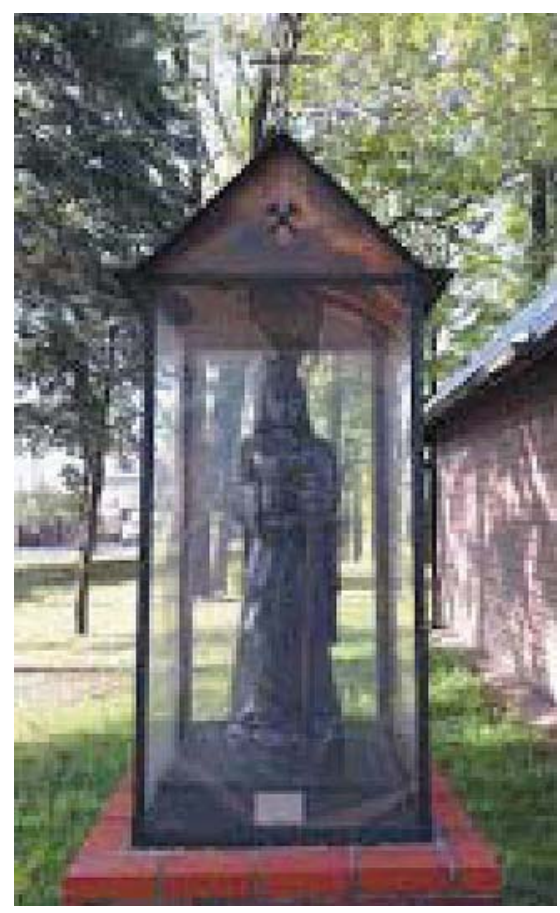

Fot. 5. Rzeźba św. Barbary z węgla przy kościele parafialnym w Ornontowicach (2018 r., fot. D. Świtała-Trybek) 
zagadnienie do omówienia) (zob. Ligęza, Żywirska, 1964, s. 156-158, 172173; Świtała-Trybek, 2011, s. 231-241). Górnicy w porannych Mszach św., odprawianych w ich intencji, bardzo licznie uczestniczą i jak sami podkreślają: „w tym dniu trza być na mszy, coby św. Barbarze podziękować za opieka za ubiegły rok i prosić o opieka na kolejny" [zapis. w Knurowie w 2012 r.]; „Św. Barbara jest naszą patronką i to jest nasz obowiązek” [zapis. w ZabrzuBiskupicach w 2011 r.]. Jednakże sam udział w porannym nabożeństwie poprzedzony jest w niektórych miejscowościach - zgodnie z dawnym zwyczajem - tzw. barbórkowymi pobudkami ${ }^{5}$, a następnie zgromadzeniem pracowników w cechowni miejscowej kopalni z kierownictwem na czele, gdzie odprawiane jest krótkie nabożeństwo do św. Barbary, po czym wszyscy zebrani w uroczystym pochodzie podążają do kościoła $^{6}$ (fot. 5 i 6). Od wielu lat przyjęło się, że w archikatedrze Chrystusa Króla w Katowicach w najbliższą niedzielę przed 4 grudnia odprawiana jest Msza św. za wszystkich górników śląskich kopalń i ich rodziny, której przewodzi metropolita górnośląski.

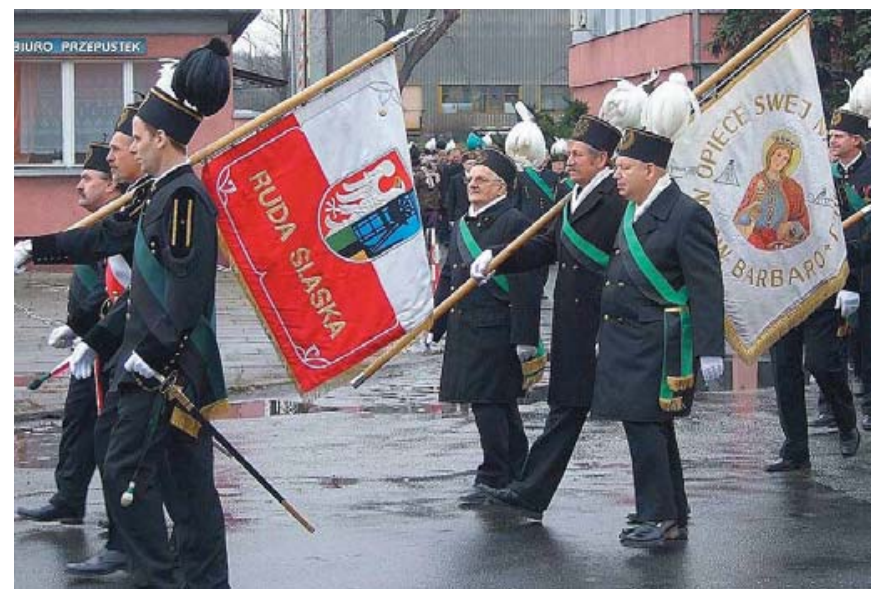

Fot. 6. Przemarsz górników z cechowni kopalni „Halemba” do kościoła (4.12.2012 r., fot. D. Świtała-Trybek)

\footnotetext{
${ }^{5}$ W dzień Barbórki, przed świtem, dęta orkiestra górnicza, wygrywając różne melodie, maszeruje po osiedlach, budząc mieszkańców (Fedorów-Skupień, Lipok-Bierwiaczonek, 2017, s. 9-31).

${ }^{6}$ Atmosferę i uroczystą oprawę tego święta w drugiej połowie XIX wieku przywołuje Anton Oskar Klaussmann: „Urzędnicy i robotnicy w pełnej górniczej gali, pod sztandarami swych kopalń i przy muzyce ściągali ze wszystkich stron do najbliższego kościoła parafialnego" (Klaussmann, 1996, s. 98). Zob. też relacje z uroczystości w Królewskiej Hucie (Chorzów); Wiadomości miejscowe i potoczne, „Gazeta Górnośląska” 1879, nr 94, s. 2-3.
} 


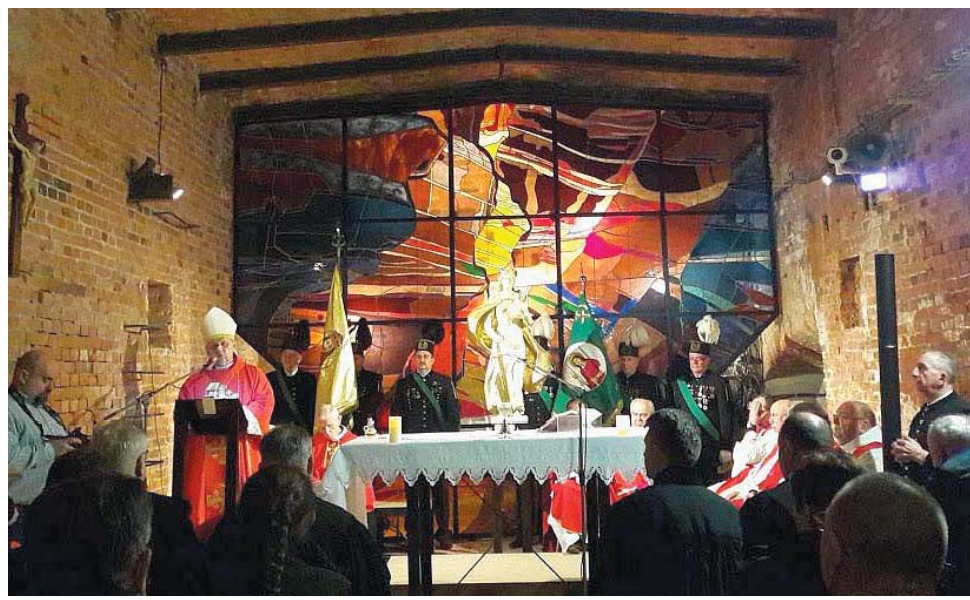

Fot. 7. Msza św. barbórkowa pod przewodnictwem bpa Jana Kopca (kaplica św. Barbary w kopalni „Guido”, $170 \mathrm{~m}$ pod ziemią, 2018 r., fot. D. Świtała-Trybek)

Z uroczystością patronalną ku czci św. Barbary związane są też charakterystyczne wierzenia, które jeszcze współcześnie funkcjonują wśród górników. Dotyczą one zwyczajowego zakazu wykonywania wówczas pracy, co ma związek z wartościowaniem czasu świątecznego (sakralnego) i wyraża się m.in. w przysłowiach górniczych, np. „Pamintej, abyś dziń świnty świnciuł, po grubie sie nie kryncił”; „Kto w Barbórka nie pije, tego w grubie zabije” (Ligęza, 1968, s. 95; Czubala, 1988, s. 420). Przysłowia te wskazują również, iż w relacjach między św. Barbarą i górnikami obowiązują reguły wynikające z zasady wzajemności do, ut des. Patronka opiekuje się nimi, ale jednocześnie wymaga wypełnienia przez czcicieli określonych praktyk kultowych (Tomicki, 1976, s. 45).

Zdaniem przedstawicieli środowisk górniczych niebezpieczny jest nie tylko 4 grudnia, ale cały okres barbórkowy, obejmujący dwa ostatnie miesiące w roku - listopad i grudzień, wtedy - ich zdaniem - ma miejsce najwięcej katastrof oraz wypadków i św. Barbara „zabiera górników do siebie”, „Św. Barbara zbiera żniwo" (Świtała-Trybek, 2014, s. 234-238). Po katastrofie w kopalni „Halemba” w 2006 roku (zginęły wówczas 23 osoby) na łamach lokalnej gazety ukazał się wiersz w gwarze śląskiej, w którym przywołano owo wierzenie, wskazując jednocześnie na opiekę św. Barbary także nad rodzinami ofiar wypadków górniczych: 
Jeszcze sie przeżegnoł, synka pocałowoł i poszeł na szychta górnik jedyn „stary” łon swoji rodzinie pszonio niy żałowoł ale był tyż chopym łod Świynty Barbary.

Razym z kamratami ściana rabowali

Skarbnik klupnył krykom i wybuchnył gaz wtynczos ujrzoł piykne światło kanś w łoddali „poć do mie Franciku, to już prziszeł czas”.

[...] I wziyna Barbara Francika do siebie bo boł dobrym chopym, takich potrzebuje chocioż niy łobejrzi słoneczka na niebie teroz $\mathrm{z}$ aniołami duszyczki fedruje.

[...] O Świynto Barbaro miyj na nich wejrzynie coby im na ziemi niczego niy brakło a jak zaś na dole jakiś kamrat zginie to weź go ku siebie, tam kaj piykne światło

(Kołodziej, 2006, s. 7)

Sposoby świętowania Barbórki ulegały wielorakim przeobrażeniom, to jednak nadal trwają i są rozpoznawalnym elementem górniczych tradycji. W 2018 roku obchodzenie Barbórki górników węgla kamiennego na Górnym Śląsku zostało wpisane na krajową Listę Niematerialnego Dziedzictwa Kulturowego. Podkreślono wówczas, iż: „Uczestnictwo w uroczystościach daje górnikom nie tylko poczucie wspólnoty, ale także godności zawodowej, bowiem Barbórka ma wymiar zarówno duchowy, jak i zawodowy. Charakteryzuje się więc silnymi walorami wspólnototwórczymi"7. Koordynatorem działań umieszczenia Barbórki na wspomnianej liście było Muzeum Górnictwa Węglowego w Zabrzu.

Na przestrzeni ostatnich dwóch stuleci kult św. Barbary wśród górników na Śląsku przyjmował bardzo wiele różnorodnych form. Jedne praktyki całkowicie zanikły, inne nadal występują, choć w zmienionym kształcie. Są też zupełnie nowe zachowania odwołujące się np. do kultury popularnej, jak chociażby tatuaże $\mathrm{z}$ wizerunkami świętej. Wszystkie one, bez względu na swoją oryginalność, są przykładem zarówno postaw konkretnych osób, jak i zbiorowości (górniczej), które - bez względu na czas, w jakim przyszło im

\footnotetext{
${ }^{7}$ http://niematerialne.nid.pl/Dziedzictwo_niematerialne/Krajowa_inwentaryzacja/Krajowa_ lista_NDK/ (18.02.2019).
} 
żyć - oczekują nieustannej opieki i wsparcia ze strony sacrum w niebezpiecznym miejscu pracy, jakim jest kopalnia.

Cześć oddawana św. Barbarze definiuje górniczą tożsamość, konstytuuje jednostkowe i wspólnotowe sposoby doświadczania religijnego kontaktu z Bogiem. Obrazy i figury patronki, zarówno te w kościołach, kapliczkach, jak i w domach, udział w uroczystościach barbórkowych stanowią jeszcze dziś bardzo czytelne przejawy kultu świętej w środowisku górniczym. Żadna inna grupa zawodowa nie wyróżnia się tak wyraźnym modelem zachowań religijnych związanych z miejscem pracy.

\section{BIBLIOGRAFIA}

ADALBERG, Samuel (1889-1894). Księga przysłów, przypowieści i wyrażeń przysłowiowych polskich. Warszawa: Druk Emila Skiwskiego.

ADAMSKI, Roman (1939). Der Barbarakult in Schlesien. Wrocław: Otto Bergmayer.

BAZIELICH, Barbara (1988). Święta Barbara - patronka górników. W: Górniczy stan w wierzeniach, obrzędach, humorze i pieśniach. Red. Dorota Simonides (s. 341-372). Katowice: Śląski Instytut Naukowy.

Brown, Peter (2007). Kult świętych. Narodziny i rola w chrześcijaństwie łacińskim. Przeł. Jacek Partyka. Kraków.

BUKOWSKA-FLOREŃSKA, Irena (2007). Rodzina na Górnym Śląsku. Katowice: Wyd. UŚ.

CichY, Stefan ks. (1998). Liturgiczny kult św. Barbary w Kościele katowickim. W: Z dziejów parafii św. Barbary w Chorzowie. Materiały sesji naukowej zorganizowanej 19 X 1996 r. w stulecie konsekracji kościoła. Red. Jerzy Myszor (s. 7-18). Chorzów.

CISZEWSKI, Stanisław (1886). Lud rolniczo-górniczy z okolic Sławkowa w powiecie olkuskim. Zbiór Wiadomości do Antropologii Krajowej, 10.

Czubala, Dionizjusz (1988). Przysłowia górnicze. W: Górniczy stan w wierzeniach, obrzędach, humorze i pieśniach. Red. Dorota Simonides (s. 409-425). Katowice: Śląski Instytut Naukowy.

DygaCZ, Adolf (2004). Święta Barbara w pieśniach. Źródła i dokumentacja. Ruda Śląska: Muzeum Miejskie im. M. Chroboka.

FEDORów-SKUPIEŃ, Agnieszka, LIPOK-BIERWIACZONEK, Maria (2017). Tradycja barbórkowej pobudki. Śląskie Prace Etnograficzne. T. 4: Śląskie zwyczaje i obrzędy doroczne. Echa przeszłości czy żywa tradycja?. Red. Krystyna Pieronkiewicz-Pieczko (s. 9-31). Katowice: Muzeum Śląskie.

Gerlich, Halina, GerLICH, Marian Grzegorz (1995). Sacrum, rodzina, tradycje. Świętowanie roku kościelnego w tradycyjnej kulturze plebejsko-miejskiej Górnego Śląska. Katowice: Wyd. Śląsk.

GERLICH, Marian Grzegorz (2003). Rytm i obyczaj. Cztery szkice o tradycyjnej kulturze górniczej. Zabrze: Muzeum Miejskie w Zabrzu.

GlogER, Zygmunt (1972). Patroni święci. W: Encyklopedia staropolska ze wstępem Juliana Krzyżanowskiego. T. 3 (s. 329-330). Warszawa: Wiedza Powszechna. 
GóRECKA, Joanna, Barbara (1976). Kult. W: Encyklopedia Katolicka. T. 2. Red. Feliks Gryglewicz, Romuald Łukaszyk, Zygmunt Sułowski (kol. 14-15). Lublin: TN KUL.

JeZIORSKI, Paweł (2005). Barbarka od XVI do XIX wieku. W: Św. Barbara i Barbarka. Red. Waldemar Rozynkowski, ks. Wojciech Miszewski (s. 63-118). Toruń: Toruńskie Wydawnictwo Diecezjalne.

JANICKA-KRZYwDA, Urszula (1988). Atrybut. Patron. Symbol. Kraków: Oddział Akademicki PTTK.

JANITZEK, Karol (1879). Pieśni o świętej Barbarze, patronce konających. Dla górników z ksiąg przez cenzurę duchowną aprobowanych. Gliwice.

JUREWICZ, Oktawiusz (1984). Historia literatury bizantyjskiej. Zarys. Wrocław: Zakład Narodowy im. Ossolińskich.

Klaussmann, Anton Oskar (1996). Górny Śląsk przed laty. Katowice: Muzeum Historii Katowic.

KoŁodZIEJ, Jan (2006). Elegia górnicza. Wiadomości Rudzkie, 48, 7.

KosSAKOwSKA-JAROSZ, Krystyna, GóRECKI, Jan ks. (2018). Przeświętne Bractwo Barbary Świętej na Górach Tarnowskich fundowane 15 Augusta 1747 r. Fotokopie pierwodruku modlitewnika, uwspółcześniona wersja zapisu, komentarze. Dzieje kultu św. Barbary. Opole.

KUPISIŃSKI, Zdzisław ks. (1997). Adwent i Boże Narodzenie w regionie opoczyńskim. Studium religijności ludowej. Warszawa: Verbinum.

KUPISIŃSKI, Zdzisław ks. (2012). Kult św. Barbary w polskiej religijności ludowej. Roczniki Teologii Fundamentalnej i Religiologii, 4, 241-257.

LigęZA, Józef (1968). Śladami tradycji. Studia nad folklorem górniczym. Bytom.

LIGĘZA, Józef, ŻYwIRSKA, Maria (1964). Zarys kultury górniczej. Górny Śląsk, Zagłębie Dąbrowskie. Katowice: Wydawnictwo Śląsk.

Liss, Mateusz (1840). Magazyn Duchowny czyli modlitwy i pieśni dla chrześciańsko-katolickich górników z różnych ksiąg nabożnych zebrane za pozwoleniem zwierzchności do druku podane. Opole.

ŁABĘCKI, Hieronim (1842). O pobożności górników polskich. Alleluja.

Minaylova, Katya (2012). Pagan Ritual Practices and Magic to Protect from Sickness in the Bulgarian Orthodox Folk Ritual Calendar. In: The Ritual Year 6. The inner and the outer the Yearbook of the sief working group on the ritual year (135-148). Red. Mare Kõiva. Tartu.

MYszor, Jerzy ks. (1993). Z dziejów kultu świętej Barbary na Śląsku (XIX i XX w.). W: Patronki polskiego górnictwa. Materiały z sesji naukowej zorganizowanej z okazji otwarcia wystawy. Zabrze: Muzeum Górnictwa Węglowego w Zabrzu [bez paginacji].

Neuling, Hermann (1902). Schlesiens Kirchorte und ihre kirchlichen Stiftungen bis zum Ausgange des Mittelalters (s. 362-363). Wrocław: E. Wohlfarth's Buchhandlung.

Nussbaumer-Keller, Marie-Louise (2004). Der Barbarazweig. Geschichten zur Advents und Weihnachtszeit. Rebstein.

OgRodowsKa, Barbara (2008). Radość wszelkiego stworzenia. Rzecz o Adwencie i Bożym Narodzeniu. Historia, tradycja, obyczaj polski. Warszawa: Verbinum.

PIECHA, Beata (2002). Barbara. Barbórka. Święta. Kult świętej Barbary na Górnym Śląsku. Literatura i sztuki piękne. Katowice: Wyd. Św. Jacka.

PIEcha-VAn Schagen, Beata (2018). Kult świętej Barbary wśród górników na Górnym Śląsku w XIX i XX wieku. T. 1. Zabrze: Muzeum Górnictwa Węglowego w Zabrzu.

PoŚPIECH, Jerzy (1987). Zwyczaje i obrzędy doroczne na Śląsku. Opole.

ROZYNKOwSKI, Waldemar (2005). Św. Barbara i Barbarka - wokół początków kultu świętej męczennicy. W: Św. Barbara i Barbarka. Red. Waldemar Rozynkowski, ks. Wojciech Miszewski (s. 9-21). Toruń: Toruńskie Wydawnictwo Diecezjalne. 
SimONiDES, Dorota (2010). Dziedzictwo kulturowe górniczego stanu. W: Katowice w 144. rocznicę uzyskania praw miejskich. Tradycje i dziedzictwo górnicze na obszarze Katowic z perspektywy XXI wieku. Red. Antoni Barciak (s. 21-31). Katowice.

SKARGA, Piotr (1936). Żywoty świętych Starego i Nowego Zakonu na każdy dzień przez cały rok do których przydane są niektóre duchowne obroki i nauki przeciw kacerstwom dzisiejszym, tam gdzie się żywot którego doktora starożytnego położył ku temu kazania krótkie na te święta, które pewny dzień w miesiącu mają. Kraków: Wydawnictwo Księży Jezuitów.

SzAFRANeK, Józef (1859). Memento mori to jest pamiętaj na śmierć. Książka zawierająca czytanie duchowne, nabożeństwo do św. Barbary panny i męczenniczki patronki szczęśliwej śmierci oraz naukę i modlitwy do chorych i konających zebrana. Bytom.

ŚwitaŁA-TrybeK, Dorota (2011). Barbórka. Przemiany w świętowaniu tradycyjnego święta górniczego (s. 231-242). Lublin: Wyd. UMCS.

ŚwitaŁA-TrYBeK, Dorota (2016). Legendy o świętej Barbarze (w wyborze). Bezpieczeństwo Pracy $i$ Ochrona Środowiska w Górnictwie, 12, 44-53.

ŚwitAŁA-TrybeK, Dorota (2015). Śladami kultu świętej Barbary (Pomorze, Warszawa). Bezpieczeństwo Pracy i Ochrona Środowiska w Górnictwie, 4, 47-52.

ŚwitAŁA-TrYBeK, Dorota (2014). Tragedia w kopalni. Kulturowe konteksty katastrof i wypadków górniczych. Opole: Wyd. Uniwersytet Opolski.

Thomas, Wiliam I., ZnANIECKI, Florian (1976). Chłop Polski w Europie i Ameryce. T. 1: Organizacja grupy pierwotnej. Uwagi wstępne Józef Chałasiński, Jan Szczepański. Tłum. Maryla Metelska. Warszawa: Ludowa Spółdzielnia Wydawnicza.

TOMICKI, Ryszard (1976). Religijność ludowa. W: Etnografia Polski. Przemiany kultury ludowej. T. 1. Red. Maria Biernacka i in. (s. 29-70). Wrocław-Warszawa-Kraków: Zakład Narodowy im. Ossolińskich.

TUREK, Krystyna (2005). Święta Barbara - patronka dobrej śmierci. Recepcja kultu w ludowym repertuarze pieśniowym Górnego Śląska. W: Problemy współczesnej tanatologii. T. 9. Red. Jacek Kolbuszewski (s. 297-303). Wrocław: Wrocławskie Towarzystwo Naukowe.

VečERKova, Eva, FrolcovÁ, Vera (2010). Evropské Vánoce v tradicích lidové kultury. Praha: Nakladatelství Vyšehrad.

Wiadomości miejscowe i potoczne (1879). Gazeta Górnoślaska, 94, 2-3.

Wolf, Helga M. (2005). Weihnachten. Kultur and Geschichte. Ein Kalendarium vom ersten Advent bis zum Dreikönigstag. Wien: Böhlau.

ZADROŻYŃSKA, Anna, BRAUn, Krzysztof (2003). Zielnik świętowań polskich, Warszawa: Twój Styl. Wydawnictwo Książkowe.

ZALEWSKI, Wincenty SDB (1989). Święci na każdy dzień. Warszawa: Wydawnictwo Salezjańskie.

\section{Strony internetowe:}

http://myslowice.naszemiasto.pl/artykul/kopalnia-myslowice-wyniesli-obraz-sw-barbary-z-cechownito,2626552,artgal,t,id,tm.html (15.02.2019).

http://niematerialne.nid.pl/Dziedzictwo_niematerialne/Krajowa_inwentaryzacja/Krajowa_lista_NDK/ (18.02.2019)

http://www.parafiambcz-wodzislaw.katowice.opoka.org.pl/index.php?option=com_content\&view=ar ticle\&id=10\&Itemid=12 (15.02.2019).

https://dziennikzachodni.pl/tatuaz-z-kopalnia-jak-tatuuja-sie-gornicy/ar/1057356 (21.02.2019). 


\title{
MATERIALNE I NIEMATERIANE PRZEJAWY KULTU ŚW. BARBARY W ŚRODOWISKU GÓRNICZYM
}

\author{
S t r e s z c z e n i e
}

Kult św. Barbary w środowisku zawodowym górników na przestrzeni ostatnich dwóch wieków przyjmował wiele zróżnicowanych form. Jego rozwój na Górnym Śląsku kształtował się od pierwszej połowy XIX stulecia i ma związek z intensywnym rozwojem przemysłu wydobywczego na tym obszarze. W artykule omówiono najbardziej charakterystyczne materialne i niematerialne przejawy czci oddawane św. Barbarze. Wspomniano o kościołach i kaplicach pod jej wezwaniem, obrazach i figurach przedstawiających patronkę górników w obiektach sakralnych oraz $\mathrm{w}$ rodzinach górniczych, modlitwach, a także o obchodzeniu 4 grudnia święta patronalnego i jednocześnie zawodowego, tzw. Barbórki, która (jako element tradycji górniczych, pielęgnowana w kolejnych pokoleniach górników) została w 2018 roku wpisana na krajową Listę Niematerialnego Dziedzictwa Kulturowego. W ostatnim czasie można zauważyć nowe praktyki wśród górników, np. wykonywanie tatuaży przedstawiających św. Barbarę.

Słowa kluczowe: Śląsk; św. Barbara; kult; górnictwo; religijność. 